\title{
Gross Anatomical Studies on the Portal Vein, Hepatic Artery and Bile Duct in the Liver of the Pig
}

\author{
F.A. Osman , Y.R. Wally, F.A. El-Nady and H.M. Rezk \\ Department of Anatomy and Embryology, Fac. of Vet. Med. Cairo University
}

\begin{abstract}
Nowadays, pig has been chosen as the potential source of organs and cells for human to overcome a sever shortage of human material for clinical transplantation especially in the last 10 years by use of genetically modified swine. Consequently, the present study was conducted to give detailed information about the distribution of the blood vessels and bile ducts and their topographic relations, which may give a useful base for the hepatic segmentation in this animal aiming to provide a correct base for surgical procedures and liver transplantation.

The present study was conducted on 33 livers of pigs. Dissection, casting and radio-opaque techniques have been applied to show the different ramifications of the portal vein, hepatic artery and bile duct systems as well as their topographic relations with proposals of hepatic segmentation.

The results revealed that, the caudate, right lateral and right medial lobes were supplied by $\mathrm{R}$. dorsalis dexter and $R$. ventralis dexter of the portal vein in addition to $R$. dexter of the hepatic artery and right hepatic duct. The quadrate, left medial and left lateral lobes were supplied by the R. sinister of the portal vein and hepatic artery and left hepatic duct.

The liver of the pig could be divided into two independent segments; right and left. These two segments were separated by a segmental plane passed from the esophageal notch dorsally to the fossa of the gall bladder ventrally.
\end{abstract}

\section{Key Words}

Liver, Portal vein, Hepatic artery, Bile duct, Pig

\section{Introduction}

Nowadays pig has been chosen as the potential source of organs and cells for humans (Cooper et al.; 2002 and Cooper; 2003) to overcome a sever shortage of human material for clinical transplantation (Mollnes and Fiane, 2003). So, pigs are generally regarded as the preferred source of xenogeneic organs especially in the last 10 years by the use of genetically modified swine (Yamada et al. 2005). The vasculature of the liver of different animals has been studied by large number of authors. However, concerning the pig only little information about the vasculature of the liver are found (Elias et al.,1954, Boulonge,1972 and Ghoshal et al.,1981). Consequently, the present study was conducted to give detailed information about the distribution of the portal vein, hepatic artery and bile duct and their topographic relations that may give a useful base for the hepatic segmentation in this animal aiming to provide a correct base for surgical procedures and liver transplantation.

\section{Material and Methods}

The present work was performed on 33 livers collected from adult freshly slaughtered apparently healthy pigs (1.5-2 years old) obtained from El- Basateen slaughter house, Cairo Governorate. In order to demonstrate the intrahepatic distribution of the portal vein, hepatic artery and bile duct, three techniques were used for injection.

\section{1-Dissection:}

Twelve fresh specimens were injected by $60 \%$ colored Gum milk latex. The specimens were preserved in formalin solution, then dissected after one 
week. The technique of (Tomsett and Wakelly, 1965) was adopted.

\section{2- Casts preparation:}

For cast preparation another twelve livers were injected with colored Kem-apoxy No 151 (consists of 2 solutions $A$ and $B$, which were mixed by a ratio 3 : 1 respectively). The vessels of the liver were injected either separately or together to show their topographic relations. The injected specimens were left for 2- 3 days to dry in the open air for solidification of Epoxy. Then the specimens were macerated in sulphric acid (98\%) for 2-3 days for corrosion. Lastly, the specimens were gently washed in running tap water until become free from the macerated tissue (Alloush, 2001).

\section{3- Radio opaque mass:}

Nine specimens (three for each blood vessel and bile duct) were injected with equal mixture of red lead oxide and turpentine oil then radiographed immediately using $42 \mathrm{KVP}-100 \mathrm{MA} \times 0.1 \mathrm{sc}$ and FFD $70 \mathrm{~cm}$. (Ozek et al., 1996).

The nomenclature used in this study was adopted according to Nomina Anatomica Veterinaria (1994), as well as those used by Abd El-Hady (2002) in the buffalo calf

\section{Results}

\section{The portal vein}

The portal vein (figs.1, 2, 3, /1, 7/3) entered the hilus of the liver between the hepatic artery dorsally and the bile duct ventrally. It immediately divided into; R. dorsalis dexter, R. ventralis dexter and then proceeded to the left as $\mathrm{R}$. sinister.

\section{R. dorsalis dexter (figs. 1, 2, /2, 7/4):}

The right dorsal branch originated from the portal vein and proceeded within the parenchyma of the dorsal part of the right lateral lobe exactly between the latter and the caudate lobe. It continued for about 2-3 cm where it bifurcated into the dorsal and intermediate branches of the right lateral lobe. It detached the following branches:

Rr. processus caudatus (figs.1, 2,3/3):
They are two small branches arising from the dorsal aspect of the right dorsal branch. The first branch is smaller and could be erupted directly from the portal vein as observed in $30 \%$ of the examined cases. The 2nd larger branch of the caudate lobe is directed dorsally in arched manner to be ramified within the major part of this lobe (figs. 1, 3/3).

\section{$R$. ventralis lobi lateralis dextri (figs .1,2, 3 /6):}

The ventral branch of the right lateral lobe proceeded ventrally for about $5-6 \mathrm{~cm}$ to be ramified into three branches in the most distal part of the right lateral lobe. Along its course, it detached 5-8 collateral branches that supply the remaining part of the right lateral lobe. Mostly (80\%) another small additional branch erupted directly from the ventral aspect of the portal vein, passed to the ventral part of the right lateral lobe.

R. intermedius lobi lateralis dextri (figs. 1, 2, 3 /5): This branch could be considered as the ventral continuation of the right dorsal branch. It proceeded ventrolaterally for about $3-4 \mathrm{~cm}$ before dividing into 2-3 branches that arborized in the corresponding part of the right lateral lobe.

\section{R. dorsalis lobi lateralis dextri (figs.1, 2, 3 /4):}

It extended dorsally for about $1-3 \mathrm{~cm}$ and then divided into two terminal branches that ramified within the right dorsal angle of the right lateral lobe.

\section{2. $R$. ventralis dexter (figs. 1, 2, 3/7, 7/8):}

The right ventral branch originated from the ventral aspect of the portal vein close to the origin of the right dorsal branch. In $20 \%$ of the examined cases it erupted by a common trunk with the latter. It proceeded ventrally for about 4-6 cm within the parenchyma of the right medial lobe. It terminated by dividing into two branches distributed to the ventral portion of the right medial lobe. Along its course, it detached several branches to the dorsal and middle parts of the right medial lobe.

\section{R. sinister:}

The left branch of the portal vein, from the point of size and direction could be considered the direct continuation of the portal vein. It proceeded transversally in a slight ventral direction within the parenchyma of the dorsal portion of the quadrate lobe as 
a transverse part (figs.1,2, /8,3/11,7/9), then directed ventrally between the quadrate and left medial lobes toward the umbilical fissure as an umbilical part (figs.1, 2, 19,3/12). The left branch supplied the quadrate lobe, left medial and left lateral lobes through the following branches.

\section{R. dorsalis lobi lateralis sinistri (figs.1, 2, 3 /13):}

The dorsal branch of the left lateral lobe arose from the dorsal aspect of the R. sinister at the junction between the Pars transversa and Pars umbilicalis. It extended dorsolaterally and terminated by several branches within the parenchyma of the dorsal half of the left lateral lobe.

R. ventralis lobi lateralis sinistri (figs.1, 2,/12,3/14): The ventral branch of the left lateral lobe emerged from the convexity of the Pars umbilicalis and divided into 2-3 branches that proceeded laterally crossing the corresponding branches of the hepatic veins to ramify within the ventral half of the left lateral lobe.

\section{Rr. lobi medialis sinistri (figs.1, 2 /11,3/15):}

Three or four branches detached from the convexity of the termination of the Pars umbilicalis. The most dorsal one is the largest and directed laterally, it distributed into the dorsal part of the left medial lobe. The other branches are smaller and directed ventrally to supply the remaining part of the left medial lobe.

\section{Rr. lobi quadrati (figs.1, 2/10,3/16):}

Two or three in number arising from the concavity of the R. sinister (umbilical part) opposite to the eruption of the branches of the left medial lobe. The first two branches are small and distributed into the dorsal part of the quadrate lobe. The last branch is larger and proceeded ventrally to the terminal part of the quadrate lobe.

\section{Portal segmentation}

The liver of the pig could be divided according to the intrahepatic distribution of the portal vein into two portal segments; right and left. The right portal segment consisted of the caudate, right lateral and right medial lobes. The left portal segment supplied the left lateral, left medial and the quadrate lobes. An oblique segmental plane passing from the eso- phageal impression dorsally to the fossa of the gall bladder could separate the two segments ventrally.

The hepatic artery:

\section{A. hepatica (figs. 4,5,6/1):}

The hepatic artery originated from the ventral aspect of the coeliac trunk, it proceeded ventrally within the pancreas where it released 4-5 pancreatic branches. It continued towards the hilus of the liver to gain the dorsal aspect of the portal vein. Before reaching the hilus of the liver, the hepatic artery divided into right and left branches. Generally, the branches of the hepatic artery within the different lobes of the liver follow the ramifications of the portal vein.

\section{R. dexter (figs. 4,5,6/2,7/2):}

The right hepatic branch arose from the right aspect of the A. hepatica dorsal to the portal fissure.It continued ventrally and to the right crossing the visceral aspect of the portal vein where it divided into $R$. dexter lateralis and $\mathrm{R}$. dexter medialis. In one of the examined cases the right branch and its ramifications follow the parietal aspect of the corresponding branches of the portal vein.

\section{$R$. dexter lateralis (figs. 4,5,6 /3):}

The right lateral branch originated from $\mathrm{R}$. dexter at the area of connection between the right lateral and right medial lobes. It proceeded laterally for about 2$3 \mathrm{~cm}$ following the tributaries of the R. dorsalis dexter of the portal vein. It supplied the right lateral and caudate lobes.

\section{A. lobi caudati (figs.4,5,6/4):}

The artery of the caudate lobe detached from the dorsal aspect of $\mathrm{R}$. dexter lateralis. It proceeded dorsally accompanied by the corresponding branch of the portal vein and ramified in the caudate lobe.

\section{R. dorsalis lobi lateralis dextri (figs4,5,6 /5):}

The dorsal branch of the right lateral lobe detached from the dorsolateral aspect of the $R$. dexter lateralis and passes toward the lateral border of the right lateral lobe, where it divided into two branches supplying the dorsal third of the right lateral lobe. It follows the tributaries of the corresponding branch of the portal vein. In $20 \%$ of the examined cases it is 
released from the $A$. hepatica directly and detached the A. lobi caudate.

\section{R. intermedius lobi lateralis dextri (figs 4,5,6/6):}

The intermediate branch of the right lateral lobe erupted from the lateral aspect of the R. dexter lateralis and considered its direct continuation. It passes laterally toward the border of the right lateral lobe following the divisions of the homonymous branch of the portal vein. It supplied the middle third of the right lateral lobe by 2-3 branches.

\section{R. ventralis lobi lateralis dextri (figs. 4,5,6/7):}

The ventral branch of the right lateral lobe detached from the ventral aspect of the right lateral branch. It proceeded ventrally for about $4-5 \mathrm{~cm}$ following the homonymous branch of the portal vein where it was divided into two branches that ramified within the ventral third of the right lateral lobe.

\section{R. dexter medialis (figs. 4,5,6/8):}

The right medial branch of $\mathrm{R}$. dexter arose from the ventral aspect of the latter and proceeded ventrally accompanied by the $\mathrm{R}$. ventralis dexter of the portal vein to the ventral border of the right medial lobe. In $10 \%$ of the examined cases it detached the A. cystica .

\section{2-R. sinister (figs. 4,5,6/11):}

The left branch of the hepatic artery, according to its size and direction, is considered the direct continuation of the hepatic artery. It originated from the latter at $2-3 \mathrm{~cm}$ from the Porta hepatis. It passed ventrally and to the left crossing the dorsal aspect of Pars transversa of the portal vein. Along its course, it detached $\mathrm{R}$. quadratus, $\mathrm{Rr}$. lobi lateralis sinistri then continued as $\mathrm{R}$. lobi medialis sinistri.

\section{R. quadratus (figs.4,5,6, /10):}

The branch of the quadrate lobe detached from $R$. sinister, a short distance from its eruption from the hepatic artery. It coursed axially accompanied by the $\mathrm{Rr}$. lobi quadrati of the portal vein. It terminated by dividing into two branches near the ventral border of the quadrate lobe.It detached the A..cystica. In $30 \%$ of the examined cases R.quadratus was released from the $\mathrm{R}$. dexter medialis (fig. 4/10).

\section{A. cystica (figs. 4,5,6,/9):}

The cystic artery originated from the R.quadratus.It passéd ventrally accompanied by the cystic duct and ramified on the visceral and parietal surfaces of the gall bladder. In $40 \%$ of the examined cases, it was released from the R. dexter (fig.6/9).

\section{Rr. lobi lateralis sinistri:}

They are two in number (dorsal and ventral), that erupted from the left branch of the hepatic artery along its course on the medial border of the left lateral lobe.

\section{R. dorsalis lobi lateralis sinistri (figs. 4,5,6 112,7/11):}

The dorsal branch of the left lateral lobe arose from the lateral aspect of the R. sinister near the origin of the homonymous branch of the portal vein and followed its ramifications within the parenchyma of the dorsal half of the left lateral lobe.

\section{R. ventralis lobi lateralis sinistri (figs. 4,5,7/13):}

The ventral branch of the left lateral lobe emerged from the R. sinister at the junction between the left lateral and left medial lobes and coursed laterally following the homonymous branch of the portal vein. It divided into 2-3 branches that ramified within the distal half of the left lateral lobe. In one of the examined cases the ventral branch of the left lateral lobe emerged from the ventral aspect of $\mathrm{R}$. sinister at its origin (figs.6/13).

\section{R. lobi medialis sinistri (figs 4,5,6 /14,7/15):}

The branch of the left medial lobe forms the ventral continuation of the left hepatic artery. It acquired a course similar to that of the homonymous branch of the portal vein. It terminated by dividing into 2-3 branches that supply the ventral portion of the left medial lobe. Along its course, it released several collateral branches to be ramified within the dorsal portion of the left medial lobe, of the liver.

\section{Arterial segmentation:}

Owing to the absence of intrahepatic anastomosis between the ramifications of the two hepatic arteries, the liver of the pig can be divided into two arterial segments; right and left. The right one consisted of the right lateral, right medial lobes and the caudate process, while the left segment consisted of the left lateral, left medial and quadrate lobes. 


\section{The Bile duct:}

\section{Ductus choledocus (figs 3/2,8,9 /1):-}

The common bile duct is formed at the Porta hepatis, ventral to the entrance of the portal vein, by the union of the cystic and the common hepatic ducts. The latter duct was formed by the confluence of the right and left hepatic ducts.

\section{Ductus cysticus (figs3/8,8, 9/2,):-}

The cystic duct considered as the direct continuation of the neck of the gall bladder .It accompanied the cystic artery dorsally for about $5-8 \mathrm{~cm}$. to join the Ductus hepaticus communis at the Porta hepatis. In $30 \%$ of the examined cases it received the R. lobi medialis dextri which drained the right medial lobe (fig, 9/9).

\section{Ductus hepaticus dexter (figs. 8,9 /4):}

The right hepatic duct was formed ventral to the initial part of the portal vein by the confluence of the $R$. processus caudatus, $R$. dorsalis, R. intermedius and $R$. ventralis lobi lateralis dextri. It proceeded to the left about $2-3 \mathrm{~cm}$. traversing the parietal aspect of the R. dorsalis dexter of the portal vein where it received the $R$. lobi medialis dextri then joined the left hepatic duct forming the common hepatic duct.

\section{R. processus caudatus (figs. 8, 9/5):}

The branch of the caudate process is formed by the convergence of 2-4 radicals, which collect the bile from the caudate lobe. It proceeded ventrally to join the Ductus hepaticus dexter..

\section{R. dorsalis lobi lateralis dextri (figs. 8,9/6):}

The dorsal branch of the right lateral lobe is represented by a slender ductule which drained the lateral border of the caudate lobe as well as the dorsal portion of the right lateral lobe by several twigs. It proceeded ventral and to the left following the course of the dorsal branch of R. dorsalis dexter of the portal vein to join the ductus hepaticus dexter.

\section{R. intermedius lobi lateralis dextri (figs. 8,9/7):}

The intermediate branch of right lateral lobe is considered as the direct continuation of the Ductus hepaticus dexter. It is formed by the convergence of 23 tributaries near the lateral border of the right lateral lobe then proceeded to the left on the parietal surface of the intermediate branch of R. dorsalis dexter of the portal vein. It drained the middle third of the right lateral lobe.

\section{R. ventralis lobi lateralis dextri (figs . $8,9 / 8$ ):}

The ventral branch of the right lateral lobe is formed by convergence of two tributaries draining the ventral third of the right lateral lobe. Each measured about 5-6 cm in length and proceeded dorsally followed the ventral branch of $\mathrm{R}$. dorsalis dexter of the portal vein. In $20 \%$ of the examined cases the ventral portion of the right lateral lobe drained by additional branch which joined the terminal part of the right hepatic duct (fig., 8/8).

\section{R. lobi medialis dextri (figs.8,9/9):}

The branch of the right medial lobe is formed by the union of two small radicals starting from the ventral portion of the right medial lobe, then proceeded dorsally about $5-8 \mathrm{~cm}$ following the left aspect of $R$. ventralis dexter of the portal vein. Along its course, it received collateral branches from the dorsal and middle portions of the right medial lobe. It joined the right hepatic duct about $1-2 \mathrm{~cm}$ before its termination into the common hepatic duct.

\section{Ductus hepaticus sinister (figs.3/10, 8,9 /11):}

The left hepatic duct is considered as the direct continuation of the common hepatic duct. It is formed by the convergence of two branches; R. lobi lateralis sinistri and $\mathrm{R}$. lobi medialis sinistri. It proceeded to the right on the ventral aspect of the Pars transversa of the portal vein for about $3-4 \mathrm{~cm}$. Along its course, it received the $\mathrm{Rr}$. lobi quadrati.

\section{R. lobi lateralis sinistri (figs. 8,9 /12):}

The branch of the left lateral lobe is formed by the confluence of dorsal and ventral branches. It proceeded ventral and to the right traversing the parietal aspect of the Pars umbliclais of the portal vein for about $2-5 \mathrm{~cm}$ where it joined the branch of the left medial lobe.

R. dorsalis lobi lateralis sinister (figs.7/13, 8,9/14): The dorsal branch of the left lateral lobe is represented by a fairly large ductule which collect the bile from the dorsal half of the left lateral lobe. It is formed by 2-4 small tributaries and measured about $3-5 \mathrm{~cm}$. It proceeded ventrally following the 
course of the homonymous branch of the portal vein.

\section{R. ventralis lobi lateralis sinister (figs.7/14, 8,9 /15):}

The ventral branch of the left lateral lobe is formed by 2-3 small ductules near the lateral border of the left lateral lobe, then proceeded dorsal and to the right for about $5-7 \mathrm{~cm}$ following the course of the corresponding branch of the portal vein. It collects the bile from the ventral half of the left lateral lobe. About $2 \mathrm{~cm}$ before its termination it received a slender branch which drained the ventromedial portion of the same lobe.

\section{R. lobi medialis sinistri (figs. 8,9/13):}

The branch of the left medial lobe is represented by a large duct which collects the bile from the left medial lobe of the liver. It is formed by two branches at the ventral potion of the left medial lobe then proceeded dorsally on the lateral aspect of the homonymous branch of the portal vein.

\section{Rr. lobi quadrati (figs. 8,9 /16):}

The branches of the quadrate lobe is represented by two ductules each joined the left hepatic duct separately about its middle.

\section{Biliary segmentation:-}

Owing to the absence of intrahepatic anastomosis between the tributaries of the bile duct the liver could de divided into two biliary segments; right and left. The right segment received the bile from the caudate process, right lateral and right medial lobes. The left segment received the bile from the left lateral, left medial and quadrate lobes.

\section{Discussion}

\section{Portal vein}

The present study revealed that, the portal vein entered the liver between the hepatic artery dorsally and the bile duct ventrally. Such results were in agreement with that given by Miller et al. (1964) in the dog; Hagras and Swielim (1990) in the sheep; Farag (1990) in the camel and Abd El-Hady (2002) in buffalo calf. The division of the portal vein into right dorsal, right ventral and left branches within the Porta hepatis as observed in this study, these in accordance with Ghoshal et al. (1981) in the horse, Osman et al. (1986) in the donkey, Arnautovic et al. (1971), Osman and Ragab (1986) and Farag (1990) in the camel. On the other hand, Vitums (1959), Miller et al. (1964), Sleight and Thomford (1970), Manderino and Devries (1985), De-Lhounta and Habel (1986) and Kalt and Stump (1991) in the dog, Horowitz and Venzke (1966) in the goat, Garner and Singleton (1953), Heath (1968) and Hagras and Swielim (1990) in the sheep, Nickel et al. (1973) and Habel (1975) in the ox, Elias and Petty (1952) in human mentioned that, the portal vein is divided into two main branches; left and right .

Regarding the eruption of the Rr. Processus caudatus from the right dorsal branch and its distribution within the caudate process presented in this work is in agreement with Happich (1961) and Klages (1962) in the sheep, Osman and Hagras (1986a) in the goat, Anis (1977), El Gaafary et al. (1979) and Abd El-Hady (2002) in buffalo, Osman et al. (1986) in the donkey, Arnautovic et al. (1971) and Osman and Ragab (1986) in the camel. However, the direct eruption of the $\mathrm{Rr}$. Processus caudatus from the portal vein mentioned by Boulonge (1972) in the pig, was observed only in $10 \%$ of the examined cases in this study.

The terminology and distribution of the R. dorsalis dexter is a matter of divergence in different species. In this connection the present work stated that, the right branch is represented by right dorsal and right ventral branches. The right dorsal branch supplied the right lateral lobe and the caudate process. Such results is matched with the right branch mentioned by, Sleight and Thomford (1970), De-Lhounta and Habel (1986) and Kalt and Stump (1991) in the dog. While, Anis (1977), El Gaafary et al. (1979) and Abd El-Hady (2002) in the buffalo reported that, the $\mathrm{R}$. dorsalis dexter supplied also the adjacent portion of the papillary process.

The present study revealed that, the $R$. ventralis dexter supplied the right medial lobe. However, Happich (1961) and Klages (1962) in the sheep, Osman and Hagras (1986a) in the goat recorded that $R$. ventralis dexter supplied the ventrolateral part of the right lobe and quadrate lobe. 
The division of the R. sinister into Pars transversa and Pars umbilicalis as stated in this work is in accordance with Osman and Hagras (1986) in the goat, Anis (1977), El Gaafary et al. (1979) and Abd El-Hady (2002) in buffalo, Nickle et al. (1973) and Habel (1975) in the ox, Osman and Ragab (1986a) and Farag (1990) in the camel. Moreover, the present work proved that, the R. sinister supplied the left lateral, left medial and quadrate lobes Similar results were observed by Coq (1965) and Coq et al. (1965) and Berenger (1966) in the dog, Osman et al.(1986) in the donkey. On the other hand, Swielim (1989) in the dog, Happich (1961) and Klages (1962) in the sheep, Osman and Hagras (1986a) in the goat, Anis (1977), El Gaafary et al. (1979) and Abd El-Hady (2002) in buffalo, Arnautovic et al. (1971), Osman and Ragab (1986) and Farag (1990) in the camel recorded that, the left branch of the portal vein supplied the left and quadrate lobes as well as the adjacent portion of the papillary process.

The current work did not observe any anastomosis between the terminal branches of the portal vein. A similar result was recorded by Farag (1990) in the camel and Abd El-Hady (2002) in buffalo. However, Julian and Deome (1949) in the cattle and Elias et al. (1954) in the pig had recorded the presence of macroscopic anastomosis between the branches of the portal vein. The anastomosis between the branches of the portal vein and those of the hepatic artery were not observed in any of the examined specimens. Such results were in agreement with Ghoshal et al. (1981) in the pig.

\section{Hepatic artery}

The division of the hepatic artery into right and left branches outside the liver observed in this study was also reported by Boulonge (1972) in the pig, Horowitz and Venzke (1966), Hagras and Osman (1986) in the goat, Hagras and Swielim (1990) in the sheep, Anis (1977) and Abd El-Hady (2002) in the buffalo and Farag (1990) in the camel. The present study revealed that, the caudate process supplied by branches from the right hepatic artery. Such results were similar to that given by Boulonge (1972) in the pig, Horowitz and Venzke (1966), Hagras and Osman (1986) in the goat and Hagras and Swielim (1990) in the sheep, Schmidt et al. (1980) in the dog, Anis (1977) in the buffalo, Osman et al.
(1986) and Dupra (1970) in some cases in the equine and Farag (1990) in the camel. On the other hand, Boulonge (1972) recorded the independent release of the $R$. processus caudatus from the $A$. hepatica in some cases in the pig, Osman et al. (1986) and Dupra (1970) in the equine, Awad (2000) in the goat and Farag (1990) in the camel. Such results were not observed in any of the examined cases.

The eruption of the R. quadratus from the R. sinister as revealed in the present work was in agreement with that of Boulonge (1972) in the pig, Horowitz and Venzke (1966), Hagras and Osman (1986) in the goat and Hagras and Swielim (1990) in the sheep, Anis (1977) and Abd El-Hady (2002) in the buffalo, Osman et al. (1986) and Dupra (1970) in equine and Farag (1990) in the camel.

The detachment of the A. cystica from the R. dexter was recorded by Boulonge (1972) in the pig, Anis (1977) and Abd El-Hady (2002) in the buffalo, Swielim (1990) in the dog, Horowitz and Venzke (1966), Hagras and Osman (1986) in the goat and Hagras and Swielim (1990) in the sheep. Such results were observed only in $30 \%$ of the examined cases, while the remaining cases declared that, the $A$. cystica detached from the R. quadratus.

The caudate process and right lateral lobe in the pig was supplied by the R. dexter lateralis as revealed in this study. The same lobes in the pig was supplied by R. dexter (Boulonge, 1972), while, in the dog they were supplied by R. lateralis dexter (Swie$\mathrm{lim}, 1990)$ and in the camel by R. dorsalis dextri (Farag, 1990). Moreover, Boulonge (1972) in the pig recorded that, the right medial lobe was supplied by branches from the R. sinister. Such results were not observed in any of the examined cases. In this connection the present study confirmed that, the R. sinister of the A. hepatica supplied the quadrate, left medial, left lateral lobes by R. quadratus R. dorsalis lobi lateralis sinistri, R. ventralis lobi lateralis sinistri and R. lobi medialis sinistri. Such results were in agreement with Osman et al. (1986) and Dupra (1970) in equine. On the other hand, Hagras and Swielim (1990) in the sheep, Anis (1977) in the buffalo and Farag (1990) in the camel asserted that, the R. sinister supplied the quadrate, left lobes and 
papillary process. Concerning the intrahepatic anastomosis between the ramifications of the two main branches of the hepatic artery, the present study revealed no anastomosis. Similar results were stated by Healey et al. (1953) and Mays and Mays (1983) in the human liver, Abd El-Hady (2002) in the buffalo and Farag (1990) in the camel.

\section{Bile duct}

The present study revealed that, the common bile duct was formed by the union of the cystic and the common hepatic duct. The latter duct was formed by the convergence of the right and left hepatic ducts. Such results were in agreement with Boulonge (1972) and Nickel et al. (1973) in the pig, May (1970) in the sheep, Raghavan and Kachroo (1964), Bevandic et al. (1967), Nickle et al. (1973), Habel (1975), Hifny et al. (1984) and Dyce et al. (1996) in the ox. On the other hand, the formation of the bile duct by the triple convergence of the right, left and cystic ducts was reported by Bevandic et al. (1967) in the sheep, Osman and Hagras (1986a) in some exceptional cases in the goat, Abd El-Hady (2002) in exceptional cases in the buffalo calf.

In agreement with Boulonge (1972), the present investigation revealed that, the branch of the right medial lobe joined the right hepatic duct. On the other hand, Osman and Hagras (1986b), Awad (2000) in the goat, Bevandic et al. (1967), in the ox, Anis (1977), Mobarak et al. (1979) and Abd El-Hady (2002) in the buffalo, observed that, the cystic duct received branches from the ventral portion of the right and quadrate lobes. Such results were observed in $20 \%$ of the examined cases.

Concerning the intrahepatic distribution of the right hepatic duct, the present study revealed that, the right hepatic duct drained the right lateral, right medial lobes and the caudate process. Such results were recorded by Boulonge (1972) in the pig. However, Coq (1965), Berenger (1966) in the dog mentioned that, the right hepatic duct drained the right lateral lobe as well as the caudate process. On the other hand, Osman and Hagras (1986), Awad (2000) in the goat, Hagras and Swielim (1990) in the sheep, Bevandic et al. (1967), in the ox, Anis (1977), Mobarak et al. (1979) and Abd El-Hady (2002) in the buffalo recorded that, the right hepatic duct drained the bile from the right lobe, caudate process and caudal portion of the papillary process. Concerning the intrahepatic distribution of the left hepatic duct, the present work revealed that, the left hepatic duct received the bile from the left lateral, left medial and quadrate lobes. Such results were in agreement with Boulonge (1972) in the pig, Hagras and Swielim (1990) in the sheep, Coq (1965), Berenger (1966) in the dog. On the other hand, Bevandic et al. (1967), in the ox, Anis (1977), Mobarak et al. (1979) and Abd El-Hady (2002) in the buffalo mentioned that, the left hepatic duct collected the bile from the left, quadrate lobes as well as the papillary process.

The present study revealed that, the hepatocystic ducts were not present in any of the examined cases. Versus results were recorded by El-Hagari (1967) in the pig and ox, Dyce (1956) and Berenger (1966) in the dog, Bevandic et al. (1967), Nickle et al. (1973), Dyce et al. (1996) in the ruminant.

The present work revealed no observable anastomosis between the two main branches of the hepatic ducts. Such results were not in agreement with Elias and Petty (1952) in the man.

\section{References}

Abd El-Hady, E.F.M. (2002):

Gross anatomical studies on the liver of buffalo calves. Thesis, M. V. SC. Cairo Univ.

Alloush, G. M. (2001):

Some anatomical studies on the heart and thoracic aorta of the goat with special ref erence to the pattern of its distribution. Ph. D. Thesis, Faculty of Veterinary Medicine, Cairo University. Egypt.

Anis, H. (1977):

Some anatomical studies on the liver of the buffalo in Egypt (Bos bubalis L.). Thesis, M. V. SC. Zagazic Univ.

Arnautovic. L, Fahmy, M.F.A. and Abdalla, O. (1971): Anatomical study of the liver of the camel (Camelus dromedarius). II.The course and distribution of the portal vein, hepatic artery and hepatic duct . Acta. Mor phol.Neerl. Scand., 9, 211-220

Awad, A.S. (2000): 
Gross anatomical study on the liver of the goat. Thesis, M V. Sc. Cairo Univ.

Berenger, A. (1966):

Segmentation hepatique chez Les carnivores These Doct. Vet., Alfort.

Bevandic, M., Arnautovic, I., Kremar, I. and Lorger, J. (1967): Comparative survey of the bile ducts of domestic animals. Veterinaria, Sarajevo, 16, 301-314.

Boulonge. J.E. (1972):

La Segmentation hepatique chez Le proc. Domestique. These Doct. Vet., Alfort.

Cooper D.K.C. (2003):

Outwitting Evolution - Progress Towards Clinicl Xenotransplantation. The journal of surgery volume 1 , issue 1, 9-14.

Cooper D.K.C., Gollackner, B., Sachs, D.H., (2002): Will pig solve the transplantation backlog? Annu. Rev. Med. 53, 133-147.

Coq, P. (1965): La segmentation hepatique des carnivores. Rec. Med. Vet. CXLI, 234-268.

Coq. P. Blin, P.C. and Berenger, A. (1965): Topographie de La.veine porte intrahepatque du chien. Rec. Med. Vet. CXLI, 6-15.

De-Lahounta and Habel (1986): Applied Veterinary Anaomy.W.B. Saunders company Philadelphia , London, Toronto, Mixieo city, Riode Janeiro, Sydney, Tokyo, Hong kong.

Dupra, P. (1970):

Segmentation hepatique chez Le cheval. These Doct. Vet. Alfort.

Dyce, K.M, Sack, W.O. and Wensing, C.J. (1996): Textbook of veterinary anatomy. $2^{\text {nd }}$ ed. W.B. Saunders company, Philadelphia, London, Toronto, Montreal, Sydney and Tokyo. Pp 136-795.

EL-Gaafary, M.A, EL-Gindy, E.M and Anis, $H$. (1979): Some morphological features on the intrahepatic part of the portal vein in buf falo in Egypt. Egypt. Vet. Med. J., 27, 6169.

El-Hagri, M.A.A. (1967): Splancnology of domestic animals. $1^{\text {st }}$ ed. Cairo Univ. Press

Elias, A. and Petty, D. (1952):

Gross anatomy of the blood vessels and ducts within the human livers. A mer.j. Anat., 90, 59-111.
Elias, H., Bond, E., Lazarowitz, A. (1954): The normal liver of the pig. Am. J. vet. Res. January 60-66

Farag, F.M.M (1990):

Some gross anatomical studies on the liver of the one humped camel (Camelus drome darius). Thesis hp. O. Vet, Med. Cairo, Univ.

Garner, R.F. and singleton, A.G. (1953): Laminar Flow in the portal vein of the sheep and goat. J. comp. That. I, 63, 300-303.

Ghoshal, N.G., Koch, T. and Popesko,P(1981): The venous drainage of the domestic animals.WB. Saunders Com. Philadelphia, London, Toronto, Sydney.

Habel, R.E. (1975):

Ruminant digestive system. In Sisson and Grossman's anatomy of the domestic animals. $5^{\text {th }}$ ed Revised by Getty, R. (1975).

WB. Saunders. Philadeliphia, London, Toronto .

Hagras, S.M. and Osman, F.A. (1986):

Parenchymal distribution of the hepatic artery of goat. Egypt. J. Histol. 9. 1, 93-96.

Hagras, S.M. and Swielim, G.E.A. (1990):

Gross anatomy on the blood vessels and bile duct in the liver of sheep. The new Egyptian. J. of Med. Vol., 1, No. 2, pp. 1066-1082.

Happich, A. (1961):

Blutgefaessversorgung der Verdaungsorgane in Bauch und Beckenhoelle, einschlieslich leber, Milz und Bauchspeichel druese beim schaf.

Healey, J.E., Schroy, P.C. and Sorensen. J.R. (1953): The intrahepatic distribution of the hepatic artery in man. J. international college of surgeons, 20, 133-148.

Heath, J. (1968): Original distribution of portal blood in the sheep. Amer.J.Anat.122, (1), 95-106.

Horowitz, A. and Venzke, W.G. (1966):

Distribution of blood vessels to the post diaphragmatic digestive tract of the goat: celiac trunk, gastroduodenal and splenic tributaries of the portal vein.

Amer. J. Vet. Res. 27, 1293-1315.

Julian, L.M. and Deome, B. (1949): Studies on the subgross anatomy of the bovine liver. Amer. J. Vet. Res., 10,331-335. 
Kalt, D.J. and Stump, J.E. (1991):

Gross anatomy of the canine portal vein. Anat. Histol. Embryol. 22, 191-197.

Klages, CH. (1962):

Anatomische Untersuchungen des Gefaessverlaufs der Leber neu-geborener Schafe und geburtsreifer Rinder.Diss. Vet. Med. Hannover.

Manderino, D., and Devries, J. G. (1985): Hepatic encephalopathy in dogs Mod.Vet. Pract. 66, 975-984

May, N.D.S. (1970):

The anatomy of the sheep. $2^{\text {nd }}$ ed. Univ. of the Queensland press.

Mays, E.T. and Mays, E.T. (1983):

Are hepatic arteries end arteries. J.Anat.., 137, 4, 637-644.

Miller, M.E., Christensen, G. and Evans, H. (1964): Anatomy of the $\operatorname{dog} 2^{\text {nd }}$ ed. W.B. Saunders, philadelphia, London.

Mobarak, A.M., EL-Gaafary, M.A. and Anis, $H$ (1979): Some anatomical studies on the liver of the buffalo in Egypt. IV. Biliary system. Egypt. Vet. Med. J., 27, 259-263.

Mollnes, T.E., Fiane, A.E. (2003).

Perspectives on complement in Xenotransplantation.Molecular Immunology 40 (2003) 135-143

Nickel, R., Schummer, A. and Seiferle, E. (1973):The viscera of the domestic animals. Verlage, Paul, Pary, Berlin and Hamburg.

Nomina Anatomica Vetrinaria (1994):

Prepared by the international committee on Veterinary Gross Anatomical Nomenclature and authorized by the eighteen ed. General Assembly of the word Association. Zurich and Ithaca, New York.

Osman, F.A. and Hagras, S.M. (1986a):

Gross anatomical study on the portal vein in the goat. Zagazic Vet. J. Vol. 13. 13, 2730 .
Osman, F.A. and Hagras, S.M (1986b):

The bile duct system of goat. Egypt. J. His tol. 9, 1, 97-100.

Osman, F.A. and Ragab, S.A. (1986): Intrahepatic veins and bile ducts of one-humped camel (camelus dromedarius). Egypt. J. Histol., 9, 2, 245-249.

Osman, F.A., Ragab, S.A., EL-Ayat, M.A. and Hagras, S.M. (1986): Anatomical studies on the liver of the donkey. Course and distribution of the portal vein, hepatic artery and bile duct. Egypt. J. Anat., 9, 149-160.

Ozek, C.; F. Zhang, W.C. Lineaweaver, B.T. Chin, L. Newlin, P. Mayer and H.J. Buncke (1996): New simplified radio-opaque injecttion technique for visualization of rat arteries. Microsurgery. Vol. 17: 321-323.

Raghavan, D. and Kachroo, P. (1964):

Anatomy of the ox.Indian council of Agricul tural Research, New Delh.

Schmidt, R.M.B., Lohse, I.L.S. and Sutur, L.J.A. (1980): Hepatic artery and liver segmentation in carnivora. Braz. 1. Res. Anim. Sci, Vo!. 28, No. L P. 19-30.

Sleight, D.R. and Thomford, N.R. (1970):

Gross anatomy of the blood supply and biliary drainage of the canine liver. Anat.Rec., 166, 153-160.

Swielim, G.E.A. (1989):

Intrahepatic distribution of the portal vein and hepatic vessels in the dog. A lex. J. Vet. Sci. 5, 2, 33-45.

Tomsett, D. H. and C. W. Wakeley (1965):

Anatomical Techniques. $1^{\text {st }}$ Edition. E \& Living Stone Ltd. Edinburgh and London.

Vitmus, A. (1959): Portal vein in the dog Zbl. Vet. Med. 6,723741

Yamada, K., Griesemer, A., Okumi, M. (2005):

Pigs as xenogeneic donors. Transplantation reviews 19 (2005)164-177. 


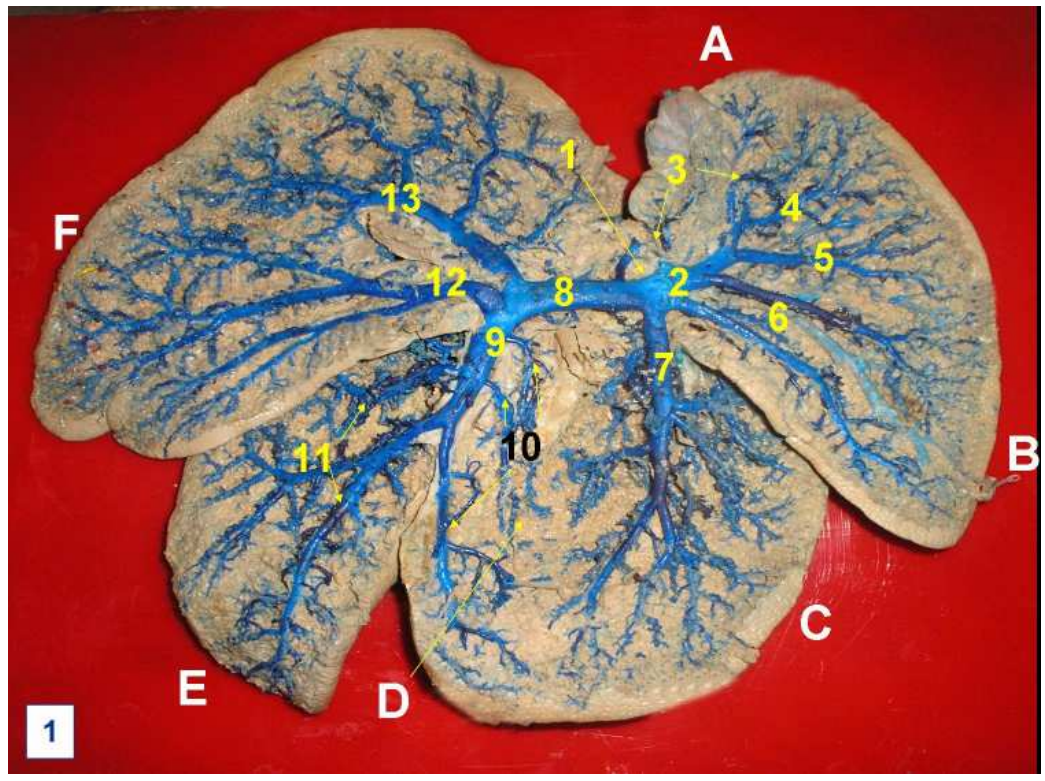

Fig. (1) A photograph showing the parenchymal distribution of the portal vein (latex injected specimen)

A Processus caudatus, B Lobus hepatis dexter lateralis, C Lobus hepatis dexter medialis, D Lobus quadratus, E Lobus hepatis sinister medialis, $\mathrm{F}$ lobus hepatis sinister lateralis

1 Venae portae, 2 R. dorsalis dexter, $3 \mathrm{Rr}$. processus caudatus, $4 \mathrm{R}$. dorsalis lobi lateralis dextri, $5 \mathrm{R}$. intermedius lobi lateralis dextri, 6 R. ventralis lobi lateralis dextri,7 R. ventralis dexter, 8 R. sinister (pars transversa), 9 R. sinister (pars umbilicalis), $10 \mathrm{Rr}$. lobi quadrati, $11 \mathrm{Rr}$. lobi medialis sinistri, $12 \mathrm{R}$. ventralis lobi lateralis sinistri, $13 \mathrm{R}$. dorsalis lobi lateralis sinistri.

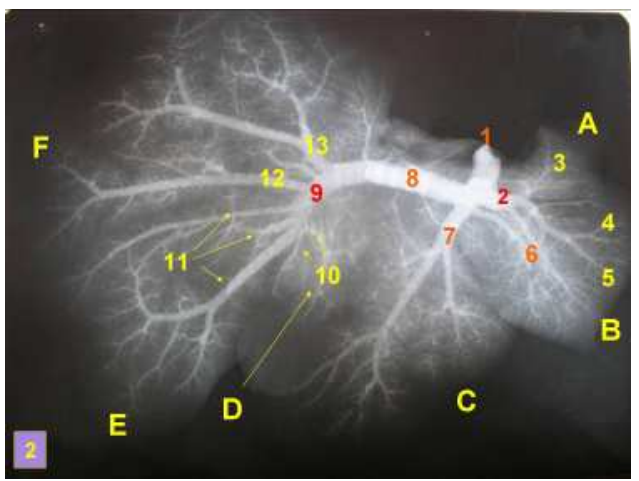

J. vet. anat.
Fig. (2) Radiograph showing the parenchymal distribution of the portal vein.

A Processus caudatus, B Lobus hepatis dexter lateralis, C Lobus hepatis dexter medialis, D Lobus quadrates, E Lobus hepatis sinister medialis, $F$ lobus hepatis sinister lateralis,

1 Venae portae, 2 R. dorsalis dexter,3 Rr. processus caudatus, 4 R. dorsalis lobi lateralis dextri, 5 R. intermedius lobi lateralis, $6 \mathrm{R}$. ventralis lobi lateralis dextri, dextri, 7 R. ventralis dexter, 8 R. sinister (pars transversa), 9 R. sinister (pars umbilicalis), $10 \mathrm{Rr}$. lobi quadrati, $11 \mathrm{Rr}$. lobi medialis sinistri, $12 \mathrm{R}$. ventralis lobi lateralis sinistri, $13 \mathrm{R}$. dorsalis lobi lateralis sinistri. 


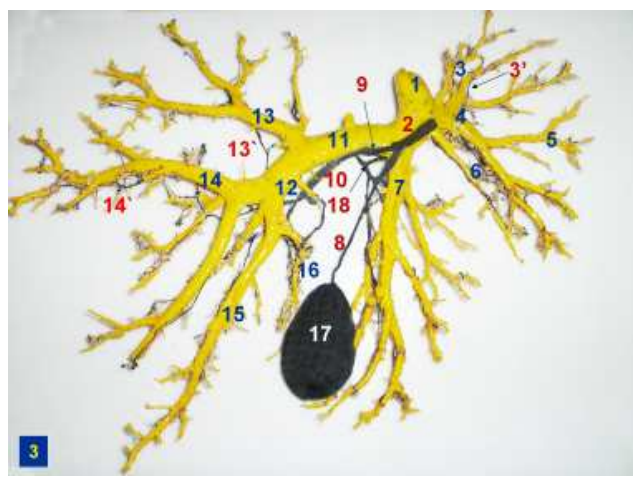

Fig. (3) Cast showing the parenchymal distribution of the portal vein (colored yellow) and bile duct (colored green).

1 Venae portae, 2 Ductus choledocus, 3 Rr. processus caudatus, 3' R. processus caudatus, 4 R. dorsalis dexter, 5 R. intermedius lobi lateralis dextri, 6 R. ventralis lobi lateralis dextri,7 R. ventralis dexter, 8 Ductus cysticus, 9 Ductus hepaticus communis, 10 Ductus hepaticus sinister, 11 R. sinister (pars transversa), 12 R. sinister (pars umbilicalis), 13 R. dorsalis lobi lateralis sinistri, 13' R. dorsalis lobi lateralis sinister, 14 R. ventralis lobi lateralis sinistri,14' R. ventrails lobi lateralis sinister, 15 Rr. lobi medialis sinistri, $16 \mathrm{Rr}$. lobi quadrati, 17 Vesicae felleae, 18 Ductus hepaticus dexter.

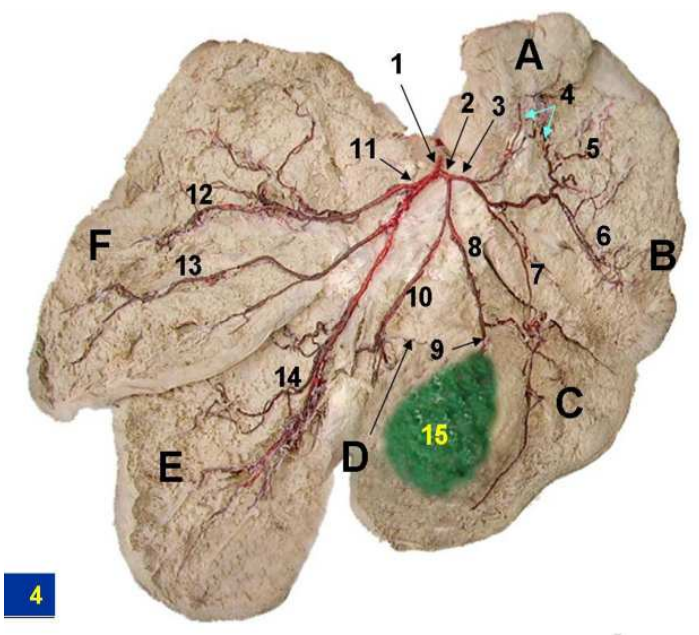

Fig. (4) A photograph showing the parenchymal distribution of the hepatic artery (latex injected specimen).

A Processus caudatus, B Lobus hepatis dexter lateralis, C Lobus hepatis dexter medialis, D Lobus quadratus. E Lobus hepatis sinister medialis, $\mathrm{F}$ lobus hepatis sinister lateralis, 1 A. hepatica, 2 R. dexter, 3 R. dexter lateralis, 4 A. lobi caudate, 5 R. dorsalis lobi lateralis dextri, $6 \mathrm{R}$. intermedius lobi lateralis dextri, $7 \mathrm{R}$. ventralis lobi lateralis dextri, 8 R. dexter medialis, 9 A. cystic,10 R. quadrates,11 $R$. sinister, 12 R. dorsalis lobi lateralis sinistri,13 $R$. ventralis lobi lateralis sinistri, $14 \mathrm{R}$. lobi medialis sinistri. 


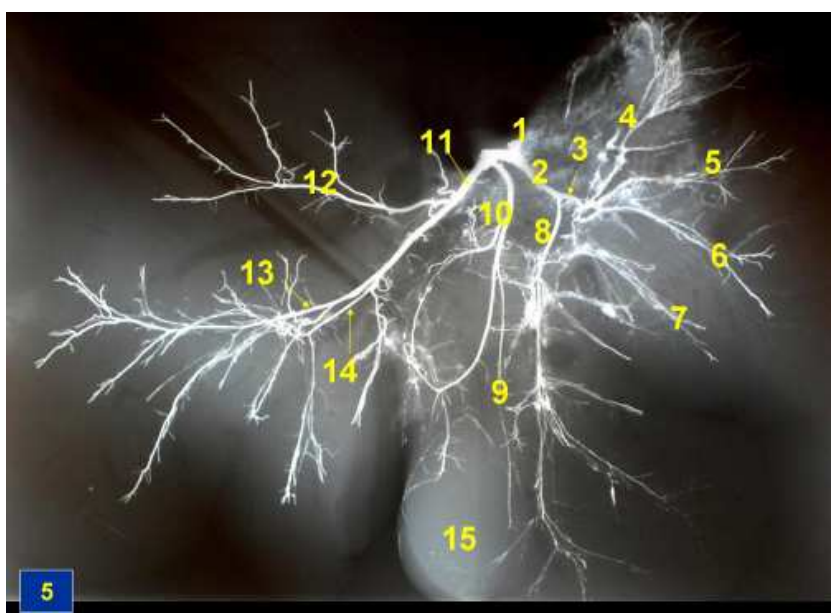

Fig. (5) Radiograph showing the parenchymal distribution of the hepatic artery.

1 A. hepatica, 2 R. dexter, 3 R. dexter lateralis, 4 A. lobi caudate, 5 R. dorsalis lobi lateralis dextri, 6 R. intermedius lobi lateralis dextri, 7 R. ventralis lobi lateralis dextri, 8 R. dexter medialis, 9 A. cystic, 10 R. quadrates, 11 R. sinister, 12 R. dorsalis lobi lateralis sinistri,13 R. ventralis lobi lateralis sinistri, 14 R. lobi medialis sinistri, 15 vesicae felleae.
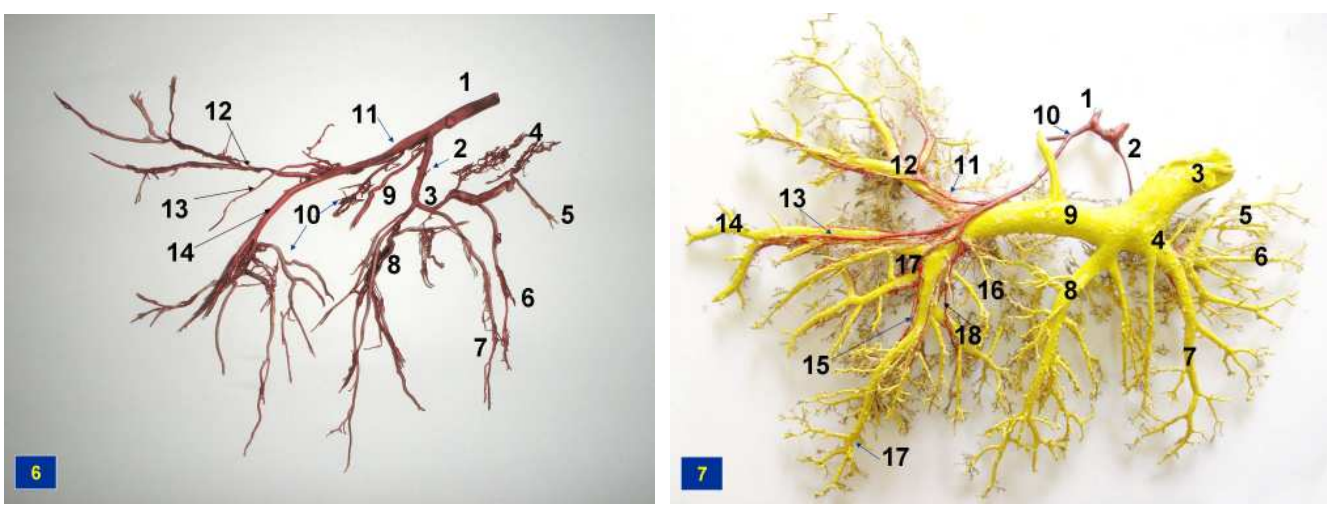

Fig. (6) Photograph of Epoxy cast showing the parenchymal distribution of the hepatic artery (visceral view).

1 A. hepatica, 2 R. dexter, 3 R. dexter lateralis, 4 A. lobi caudati. 5 R. dorsalis lobi lateralis dextri, 6 R. intermedius lobi lateralis dextri, 7 R. ventralis lobi lateralis dextri, 8 R. dexter medialis, 9 A. cystic, 10 R. quadrates, 11 R. sinister, 12 R. dorsalis lobi lateralis sinistri, $13 \mathrm{R}$. ventralis lobi lateralis sinistri, $14 \mathrm{R}$. lobi medialis sinistri.

Fig. (7) Photograph of Epoxy cast showing the parenchymal distribution of the portal vein (colored yellow) and hepatic artery (colored red). 1 A. hepatica, 2 R. dexter, 3 Vena portae, 4 R. dorsalis dexter, 5 Rr. processus caudatus, 6 R. dorsalis lobi lateralis dextri, 7 R. intermedius lobi lateralis dextri, 8 R. ventralis dexter, 9 R. sinister (pars transversa), 10 R. sinister.,11 R. dorsalis lobi lateralis sinistri, $12 \mathrm{R}$. dorsalis lobi lateralis sinistri, $13 \mathrm{R}$. ventralis lobi lateralis sinistri, $14 \mathrm{R}$. ventralis lobi lateralis sinistri. $15 \mathrm{R}$. lobi medialis sinistri, $16 \mathrm{Rr}$. lobi quadrati, $17 \mathrm{Rr}$. lobi medialis sinistri, $18 \mathrm{R}$. quadratus. 


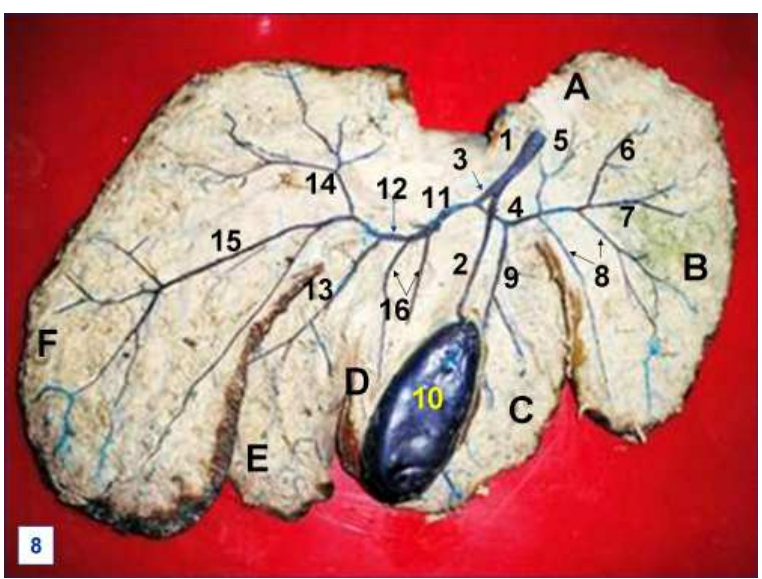

Fig. (8) A photograph showing the parenchymal distribution of the bile duct (latex injected specimen) .

A Processus caudatus, B Lobus hepatis dexter lateralis, C Lobus hepatis dexter medialis, D Lobus quadrates, E Lobus hepatis sinister medialis, $\mathrm{F}$ lobus hepatis sinister lateralis,

1 Ductus choledocus, 2 Ductus cysticus. 3 Ductus hepaticus communis. 4 Ductus hepaticus dexter. 5 R. processus caudatus, 6 R. dorsalis lobi lateralis dextri.7 R. intermedius lobi lateralis dextri. 8 R. ventralis lobi lateralis dextri.9 R. lobi medialis dextri. 10 vesicae felleae. 11 Ductus hepaticus sinister.12 R. lobi lateralis sinistri.13 R. lobi medialis sinistri.14 R. dorsalis lobi lateralis sinister.15 R. ventralis lobi lateralis sinister.16 Rr. lobi quadrati.

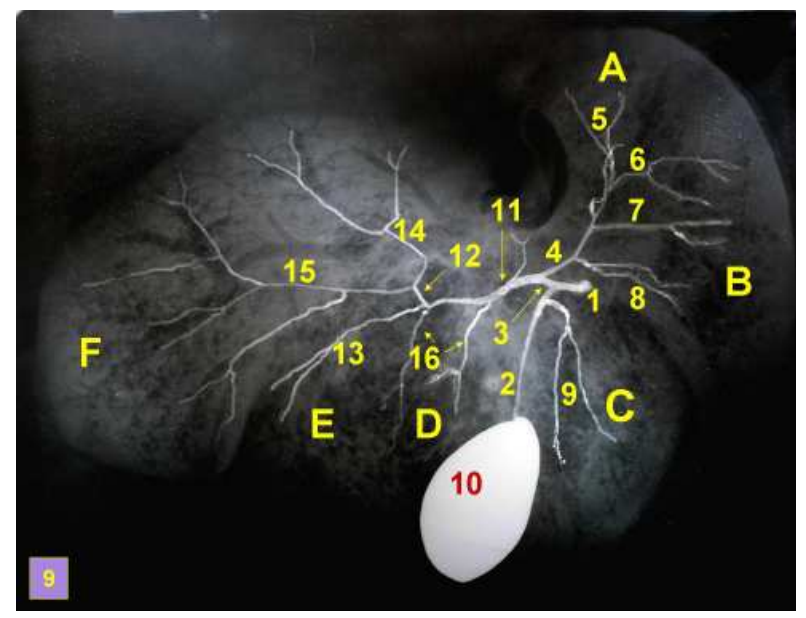

Fig. (9) Radiograph showing the parenchymal distribution of the bile duct.

A Processus caudatus. B Lobus hepatis dexter lateralis. C Lobus hepatis dexter medialis. D Lobus quadratus. E Lobus hepatis sinister medialis. $\mathrm{F}$ lobus hepatis sinister lateralis,

1 Ductus choledocus, 2 Ductus cystic, 3 Ductus hepaticus communis, 4 Ductus hepaticus dexter, 5 R. processus caudatus, 6 R. dorsalis lobi lateralis dextri, 7 R. intermedius lobi lateralis dextri, 8 R. ventralis lobi lateralis dextri, 9 R. lobi medialis dextri, 10 Vesicae felleae, 11 Ductus hepaticus sinister, 12 R. lobi lateralis sinistri, 13 R. lobi medialis sinistri, 14 R. dorsalis lobi lateralis sinister, $15 \mathrm{R}$. ventralis lobi lateralis sinister, $16 \mathrm{Rr}$. lobi quadrati. 